DOI: $10.17951 /$ rh.2018.46.283-300

\author{
Marzena Marczewska \\ (Uniwersytet Jana Kochanowskiego w Kielcach) \\ https://orcid.org/0000-0002-2796-1317
}

\title{
Stereotypy etniczne we współczesnym polskim dyskursie publicznym
}

\author{
Ethnic Stereotypes in Contemporary Polish Public Discourse
}

\section{STRESZCZENIE}

Stereotyp traktuję jako rodzaj potocznej konceptualizacji rzeczywistości, składnik językowego obrazu świata i kodu językowo-kulturowego. W artykule koncentruję się na sposobach manipulowania wybranymi stereotypami etnicznymi (Niemca, Rosjanina, Żyda) we współczesnym polskim dyskursie publicznym. Wykorzystuję różnorodne dane językowe: tzw. dane systemowe i teksty (artykuły prasowe, posty internetowe, wypowiedzi polityków i internautów w mediach społecznościowych, teksty semiotycznie złożone: wypowiedzi graficzne i werbalno-graficzne). Pokazuję, jak negatywne elementy stereotypów wykorzystywane są w medialnej walce politycznej.

Słowa kluczowe: stereotypy, językowy obraz świata, manipulacja, język polityki

Stowa moga być jak maleńkie dawki jadu, a jednak po pewnym czasie wywołuja trujace działanie.

V. Klemperer, LTI, Notatnik filologa

Za Jerzym Bartmińskim przyjmuję, że wiedza stereotypowa jest zakorzeniona w naszej świadomości, a opinie obiegowe są przez język nie tylko utrwalane, ale i upowszechniane. Stereotypy stanowią składnik językowego obrazu świata i kodu językowo-kulturowego, są nieuniknione i nieusuwalne ${ }^{1}$, ich funkcje psychospołeczne, tj. bycie narzędziem szybkich

1 J. Bartmiński, Nasi sąsiedzi w oczach studentów, w: Narody i stereotypy, red. T. Walas, Kraków 1995, s. 259-260. 
ocen i integrowania wspólnoty, są wtórne wobec funkcji poznawczych ${ }^{2}$. Stereotypy tkwią w nas, we wspólnotowym oglądzie świata, bywają też aktywowane częściej niż sobie to uświadamiamy ${ }^{3}$. W kulturze narodowej nagromadzone zostają różnorodne, bogate dane. Nigdy nie zostają one całkowicie zapomniane, są kulturowo dziedziczone i w sprzyjającym momencie mogą zostać ponownie aktywizowane. Dlatego stereotypy są wykorzystywane (a nawet nadużywane) propagandowo ${ }^{4}$. Stanowią bowiem źródło wiedzy prostej, dostępnej, łatwo przyswajalnej, niekwestionowanej, zbiorowej.

Przypomnijmy, że cechą charakterystyczną stereotypu semantycznego jest subiektywna generalizacja, często uproszczona i nieprecyzyjna (np. każdy Szkot jest skąpy, każda matka kocha swoje dzieci, każdy Polak jest gościnny). Te uproszczone sądy o świecie zmagazynowane są w języku, który nie tylko akumuluje określoną wiedzę o świecie, ale także tę wiedzę w specyficzny sposób upowszechnia. Przedstawione przeze mnie analizy odwołują się do zasad tzw. definicji kognitywnej, która wykorzystując wiedzę potoczna, koncentruje się nie tylko na elementach wartościujących, ale przede wszystkim na aspektach poznawczych. W artykule

2 J. Bartmiński, I. Lappo, U. Majer-Baranowska, Stereotyp Rosjanina i jego profilowanie we współczesnej polszczyźnie, „Etnolingwistyka” 2002, 14, s. 106-107; I. Lappo, Profilowanie stereotypu Rosjanina w polskim kręgu językowo-kulturowym, „Etnolingwistyka” 2002, 14, s. $153-174$.

3 Prekursorem badań nad stereotypami etnicznymi w Polsce był Jan Stanisław Bystroń, którego Megalomania narodowa (wydana jako artykuł w 1923 r.) przedstawia podstawowe (i ciągle aktualne) mechanizmy myślenia o obcych. Chociaż znacznie częściej w literaturze językoznawczej przywołuje się definicję stereotypu Waltera Lippmanna (1922), należy zauważyć, że Bystroń również wskazywał na podstawowe cechy stereotypu. W. Lippmann mówił o stereotypie jako "uproszczonym obrazie w głowie”, natomiast Bystroń o „zbiorowych wyobrażeniach" dotyczących poszczególnych narodów. Dla Lippmanna stereotypowe myślenie to rezultat ograniczonych możliwości poznawczych człowieka, który jednak musi funkcjonować w danym społeczeństwie, stąd korzysta z obrazów, które zapewnia mu jego własna kultura. Dla Bystronia natomiast stereotyp (zbiorowe wyobrażenie) jest konstrukcją ujawniającą psychiczne kompleksy, uprzedzenia, lęki. Por. A. Niewiara, Polskie stereotypy narodowe w świetle badań diachronicznych, „LingVaria” 2010, 2 (10), s. 171-172.

4 J. Bartmiński, J. Panasiuk, Stereotypy językowe, w: Encyklopedia kultury polskiej XX wieku, t. 2: Wspótczesny język polski, red. J. Bartmiński, Wrocław 1993, s. 369.

5 Por. wspomnienie opublikowane w "Gazecie Wyborczej": "Jednym ze szkolnych wyzwisk był u nas «żydek». Nie wiedzieliśmy, kim jest «żydek», ale nie chcieliśmy nim być. Niedaleko tej szkoły stał murowany przystanek autobusowy, najczęściej pomazany farbą. Koślawe litery często układały się w «Jude raus», choć w naszej szkole nie uczono niemieckiego (kilka lat później dowiedziałem się, że niedaleko przystanku znajdował się przed wojną żydowski sklep). Czy byliśmy antysemitami? Nie wiedzieliśmy nawet, kim są Żydzi, a jednak jakieś złe ziarno w naszych głowach kazało uznać, że być «żydkiem» to coś uwłaczającego.", http://wyborcza.pl/duzyformat/1,127290,18447691,dlaczego-5-tyspolakow-polubilo-mem-z-muzulmanami-i-torami.html [dostęp: 20 X 2017]. 
korzystam z opracowanych wcześniej rekonstrukcji stereotypów etnicznych związanych z narodowościami, które dla Polaka od zawsze utożsamiane są z obcością: Żyda, Rosjanina, Niemca ${ }^{6}$.

Trzeba pamiętać, że kategorie obcości i swojskości należą do podstawowych kategorii antropologicznych i są charakterystyczne dla wszystkich społeczności, które określają własną tożsamość na podstawie kontaktów z innymi. Anna Pajdzińska traktowała opozycję swojskości-obcości jako najważniejszą kategorię pojęciową organizującą językowy obraz świata ${ }^{7}$. Podejrzliwość wobec obcych, nieufność, strach przed wrogiem bywa wiązana z ludzką natura, to cechy utrwalone biologicznie, sprzyjające przetrwaniu ${ }^{8}$. Wolimy to, co swojskie, co znamy, boimy się obcego, nieznanego. Stereotyp jest konstruktem zawierającym uogólnioną wizję rzeczywistości, która jest dana jednostce przed doświadczeniem, niezależnie od niego, ale która wywiera znaczny wpływ na nasz ogląd rzeczywistości. Stereotypy są nieelastyczne, tzn. oporne na zmiany, i długotrwale powtarzalne (przez wiele generacji). Zawsze też zawierają w sobie pewną ambiwalencję: obok ocen negatywnych występują cechy pozytywne. Stereotyp jest związany $\mathrm{z}$ wartościowaniem i emocjonalnym stosunkiem nosiciela stereotypu do rzeczywistości, do której ten stereotyp się odnosi. Przyjmuję pojęcie stereotypu wypracowane przez etnolingwistykę lubelską: jest „sądem wartościującym (negatywnym lub pozytywnym) połączonym z przekonaniem", sądem, którego przedmiotem są jakieś grupy ludzi. Jest to sąd: emocjonalny i niezależny od doświadczenia osobistego, całkowicie lub częściowo sprzeczny z faktami, oporny na zmiany, związany ze słowem-nazwą. Stereotyp jest rekonstruowany na podstawie danych językowych, do których należą: nazwy i ich podstawa onomazjologiczna odkrywana w toku analizy strukturalnej i etymologicznej, definicje słownikowe; derywaty słowotwórcze, które przejmują i uwydatniają ukryte konotacje nazwy bazowej, często eksponując nie tylko in-

6 W dalszej części rozważań przytaczam dane pochodzące $\mathrm{z}$ następujących publikacji: M. Marczewska, Żyd - obraz utrwalony w języku, w: Z przeszłości Żydów polskich od XVI do końca XX wieku. Polityka - Gospodarka - Kultura - Społeczeństwo, red. R. Renz, J. Wijaczka, Kraków 2005, s. 391-403; eadem, Swój i obcy w mieście - kilka uwag o stereotypie kielczanina (rzecz o stosunkach polsko-żydowskich), „Etnolingwistyka” 2007, 19, s. 163-173; J. Bartmiński, I. Lappo, U. Majer-Baranowska, op. cit., s. 105-151; I. Lappo, Profilowanie stereotypu Rosjanina w polskim kręgu językowo-kulturowym, „Etnolingwistyka” 2002, 14, s. 153-174; J. Bartmiński, Zmiany stereotypu Niemca w Polsce. Profile i ich historyczno-kulturowe uwarunkowania, w: Profilowanie w języku i tekście, red. J. Bartmiński, R. Tokarski, Lublin1998, s. 225-236.

7 A. Pajdzińska, My, to znaczy... (z badań językowego obrazu świata), „Teksty Drugie: teoria literatury, krytyka, interpretacja" 2001, 66, 1, s. 34 .

8 R.S. Robins, J.M. Post, Paranoja polityczna: psychopatologia nienawiści, Warszawa 1999, s. 92-93. 
formacje dodatkowe, ale pokazując nacechowanie emocjonalne wiązane z przedmiotem opisu przez użytkownika języka; przekształcenia metaforyczne (tzw. derywaty semantyczne); frazeologizmy, utarte kolokacje (frazemy), metafory. W rekonstrukcji szczególnie doceniane są ustabilizowane połączenia wyrazowe, zwłaszcza frazeologizmy; teksty i sposoby funkcjonowania w nich wyrażeń; gramatyka (którą Jerzy Bartmiński nazywa „najtwardszą podstawą rekonstrukcji językowego obrazu świata JOS"); dane przyjęzykowe, czyli utrwalona społecznie wiedza o świecie, którą dysponują nadawca i odbiorca, połączona z przekonaniami i wierzeniami, uwidaczniająca się np. w skonwencjonalizowanych zachowaniach; ankiety badające stan aktualnej wiedzy o świecie, jaką dysponują użytkownicy języka, ujawniające różny stopień stabilizacji (utrwalenia) poszczególnych cech przypisywanych badanym obiektom? .

W artykule wykorzystałam różnorodne dane językowe, przede wszystkim jednak interesowała mnie powtarzalność pewnych charakterystyk $\mathrm{w}$ artykułach prasowych, postach internetowych, wypowiedziach polityków i internautów w mediach społecznościowych ${ }^{10}$. Zdając sobie sprawę ze specyfiki Internetu jako narzędzia debaty, zwracałam uwagę przede wszystkim na cechy powielane. Włączyłam do rozważań również teksty semiotyczno-złożone, czyli wypowiedzi graficzne i werbalno-graficzne ${ }^{11}$ (szczególnie w postaci memów i okładek czasopism), które wykorzystują elementy stereotypowe w propagandzie.

Socjotechnika manipulacji opartej na wykorzystywaniu stereotypów etnicznych polega na nadawaniu ludziom, instytucjom lub działaniom określonych charakterystyk (etykiet), aby wytworzyć w społeczeństwie pożądane postawy i wywołać zakładane działania, głównie oparte na emocjach ${ }^{12}$. Jak pokazuje historia, stereotyp może być skutecznym narzę-

9 Przywołuję ustalenia zawarte w wielu pracach J. Bartmińskiego, np.: J. Bartmiński, Pojęcie językowego obrazu świata i sposoby jego operacjonalizacji, w: Jaka antropologia literatury jest dzisiaj możlizwa?, red. P. Czapliński, A. Legeżyńska, M. Telicki, Poznań 2010, s. 155-178.

10 Cytowany $\mathrm{w}$ pracy materiał pochodzi z publikacji internetowych (internetowe wydania gazet i czasopism: wyborcza.pl, polityka.pl, newsweek.pl, wprost.pl), z postów polityków i publicystów zamieszczanych w mediach społecznościowych (Facebook, Twitter), postów na forach internetowych (komentarze pod artykułami). Teksty przytaczam $\mathrm{w}$ oryginale.

11 W. Chlebda, O źródłach, celach i drogach postępowania etnolingwistycznego w badaniach porównawczych, „Studia Slavica. Slovanské Studie” 2010, 14, s. 121-134.

${ }_{12} \mathrm{Na}$ opozycję swój - obcy jako podstawową zasadę opisującą komunikację propagandową i perswazyjną w nowomowie/pisomowie wskazywał Michał Głowiński (Nowomowa i ciagi dalsze. Szkice dawne i nowe, Kraków 2009), Paweł Nowak analizował jej przejawy w języku lat 1950-1954 (Swoi i obcy w językowym obrazie świata: język publicystyki polskiej z pierwszej połowy lat pięćdziesiatych, Lublin 2002). Konfliktowi i potrzebie poszukiwania/kreowania wroga poświęcono wiele artykułów w tomie Język w IV Rzeczy- 
dziem w walce politycznej (przekonująco omówiła to np. Irena Kamińska-Szmaj na przykładzie języka propagandy politycznej w prasie 19191923) ${ }^{13}$. Ludzie bowiem bardzo łatwo przyjmują retorykę, w której innych/ obcych uważa się za wrogów i obciąża winą za własne niepowodzenia ${ }^{14}$.

Stanisława Niebrzegowska-Bartmińska zauważyła, że „demon obcego" pojawił się w retoryce PiS-u już w latach tzw. IV RP ${ }^{15}$, kiedy w kampanii wyborczej użyto argumentu dziadka $z$ Wehrmachtu ${ }^{16}$ i dodano do tego określenia: prorosyjska lewica, wpływy żydowskie, fascynacje Niemcami. W ten sposób pojawiły się trzy stereotypy etniczne, o których wspominam $\mathrm{w}$ artykule. Często są łączone: $\dot{z}$ ydowski, rosyjski $i$ niemiecki antypolonizm (powszechne np. w tekstach publicysty związanego z Radiem Maryja Stanisława Michalkiewicza: Niemcy, Rosjanie i Żydzi dąża do likwidacji Polski). Zastanawiające są też analizy dotyczące polskiego myślenia o obcych i strachu przed uchodźcami. Wskazują one, że Polacy są wyjątkowo podatni na manipulację umiejętnie wykorzystującą wybrane elementy określonych stereotypów etnicznych ${ }^{17}$.

\section{I. ŻYD - NASZ WRÓG ODWIECZNY}

Alina Cała podkreśla, że Żyd wywoływał niepomiernie więcej emocji niż przedstawiciele innych mniejszości narodowych ${ }^{18}$. Kontaktom polsko-żydowskim towarzyszyły często wrogość i niechęć, co jest dosyć mocno

pospolitej, red. M. Czerwiński, P. Nowak, R. Przybylska, Lublin 2010. Wykorzystywanie antagonizmów i konfliktów w narracjach medialnych analizował m.in. Jacek Wasilewski, Opowieści o Polsce. Retoryka narracji, Warszawa 2012.

13 I. Kamińska-Szmaj, Judzi, zohydza, ze czci odziera. Język propagandy politycznej w prasie 1919-1923, Wrocław 1994.

14 Por. R. Girard, Kozioł ofiarny, Łódź 1987.

15 IV RP, IV Rzeczpospolita - hasło medialne łączacce się z postulatem reformowania ustroju państwa polskiego. Por. też artykuł Pawła Śpiewaka, Pięć lat po czwartej. Dlaczego wymyślitem IV RP, https://www.polityka.pl/tygodnikpolityka/kraj/1506800,1,dlaczego-wymyslilem-iv-rp.read [dostęp: 9 VI 2018].

16 S. Niebrzegowska-Bartmińska, Aksjologiczne tło demonizacji przeciwnika w kampanii wyborczej 2007 roku, w: Język IV Rzeczypospolitej, s. 352.

17 Por. http://interwencjaprawna.pl/docs/ARE-116-uprzedzenia-mlodych-polakow.pdf [dostęp: 15 XII 2017].

18 A. Cała, Wizerunek Żyda w polskiej kulturze ludowej, Warszawa 1992. Jak wspomina A. Niewiara, niechęć do Żydów w opisach pamiętnikarskich ujawniła się w XVIII w. i rozkwitła w XIX w.: „Jest to spowodowane dwoma faktami: podniesieniem materialnego statusu Żydów, który zagroził pozycji szlachty, oraz utratą niepodległości. W tej drugiej sytuacji Polak poszukuje winnego". Por. A. Niewiara, Wyobrażenia o narodach w pamiętnikach i dziennikach z XVI-XIX wieku, Katowice 2000, s. 214-221. 
poświadczone $\mathrm{w}$ języku polskim ${ }^{19}$. Wystarczy przywołać nazwy używane na określenie Żyda/Żydówki, por. np.: Żydek, Żydziucha, Żydowin, Izraelita, jarmułkowy, starozakonny, parch ${ }^{20}$, parszywiec, kasztan, pejsak, cybuch, chałaciarz, chałatowicz, kacap, kapciuch, kapociarz, kłapciuch, krymkes, męczychryst, obrzezaniec, obrzynek, rabin, stary zakon, niedowiarek, niewiara, pogan, Juda, Judasz, Kajfasz, Srul, Jemrej, Gudłaj itd..$^{21}$ Jak widać, wiele nazw ma charakter prześmiewczy, lekceważący. Są one urabiane od negatywnie nacechowanych wyrazów pospolitych związanych z wyglądem, odrębnością religijną lub od imion uważanych przez Polaków za typowe dla nacji żydowskiej. Apelatywizacja etnonimu Żyd zazwyczaj idzie w parze z pejoratywizacją ${ }^{22}$.

Charakterystyczne są definicje w starszych słownikach języka polskiego, np. Słownik języka polskiego, tzw. warszawskii ${ }^{23}$, podaje następującą definicję: „,1. Żyd - człowiek, którego pierwotną religią jest pieniądz, szachraj, handlarz, kramarz, tandeciarz, kutwa, skąpiec, chciwiec, zdzierca, wyzyskiwacz". Wiele informacji utrwalonych jest w derywatach semantycznych funkcjonujących $w$ gwarach polskich. Prawie wszystkie przykłady są zabarwione emocjonalnie i zawierają element oceny, co pośrednio wskazuje na negatywny stosunek chłopów do Żydów, np. żyd/zyd - 'kwiat i nasienie łopianu/ostu' (czyli tzw. dziad, cecha presuponowana: czepliwość, nachalność); 'człowiek chytry, przebiegły'; 'kupiec'; 'gospodarz, który handluje wódką i kiełbasą'; 'grzyb niejadalny' (twardzioszek przydrożny); 'heretyk', 'poganin', 'niedowiarek', 'bezbożnik'; żydówka 'ropna krostka, wrzód, ropień, z którego wychodzi rdzeń'; 'palec w zgięciu'; ' 'mały pęcherz na palcu'; 'nowotwór na ciele ludzkim'.

19 Polska aż do połowy XVII w. była krajem bardzo sprzyjającym Żydom. Przeżywali oni tu czas rozwoju i pomyślności, chociaż w innych krajach chrześcijaństwa byli prześladowani. Niezwykły status Żydów polskich dziwił nawet legata papieskiego, który pisał: „W tych regionach spotyka się mnóstwo Żydów, którzy nie są w pogardzie, jak to się dzieje gdzie indziej. Nie żyją w poniżeniu i nie muszą wykonywać zawodów nikczemnych. Posiadają ziemię, zajmują się handlem, studiują medycynę i astronomię. Mają wielkie bogactwa i nie tylko są zaliczani między ludzi honoru, lecz czasem nad owymi panują". Cyt. za: J. Delumeau, Strach w kulturze Zachodu XIV-XVIII w., Warszawa 1986, s. 260.

20 1. choroba roślin wywołana przez grzybki pasożytnicze, polegająca na tworzeniu się na owocach, pędach i liściach roślin różnego rodzaju plam i narośli; 2 . choroba owłosionej skóry głowy wywoływana przez grzyb woszczynowy; strupień woszczynowy, grzybica woszczynowa. Por. np. hasło parch w: Słownik języka polskiego, red. W. Doroszewski, wersja internetowa: http://www.sjpd.pwn.pl/haslo/parch/ [dostęp: 26 I 2019].

${ }_{21}$ Por. np. M. Brzezina, Polszczyzna Żydów, Warszawa-Kraków 1986, s. 89-97.

${ }^{22}$ I. Kamińska-Szmaj, op. cit., s. 111.

23 J. Karłowicz, A. Kryński, W. Niedźwiedzki, Słownik języka polskiego, t. 8, Warszawa 1927, s. 732. 
Charakterystyczny obraz utrwalony jest też w przysłowiach ${ }^{24}$. Dla stereotypowego obrazu Żyda ważny jest: wygląd zewnętrzny: Brodaty jak Żyd; Hej Żydku, na bok z broda; Koszerzy sie jak Żyd na pejsach; Ma dzieci jak Żyd czapek; Wyglada jak żydowska flądra (bardzo brudny); Żyd Żydowi pejsów nie obedrze; Obeznat się z tym jak Żyd z krymka (dobrze się na czymś znać); cechy charakteru, przede wszystkim nieuczciwość i chciwość: Jak nie ma w niebie dnia bez świętego, tak nie ma w świecie Żyda poczciwego'; Żyd uczciwym, wariat szczéśliwym, a nieboszczyk żywym być nie może; Najpoczciwszy Żyd szubienicy wart; Na Żyda tak rachować można jak na zły zegarek; Żeby Żyd był z nieba, wierzyć mu nie trzeba; Wszystkie Żydy złodzieje, a rabin największy; Żyda tylko diabeł oszuka; Żyd nie byłby Żydem, gdyby nie oszukat; Żyd dawno szalbierz (oszust); Trzeba bardzo rano wstać, żeby Żyda oszukać; Żyda by oszukat (o człowieku nadzwyczajnego sprytu); Żyda dziś oskub z pierza, to na jutro już porośnie; Jak sprzedać psa za lisa, żydowska jest sztuka; Żydowska piosenke mu śpiewa (o usiłowaniu przekupienia kogoś); Co Żyd to cygan; Wilk i Żyd nigdy niesyt; Gdzie Żyd łeb wsadzi, tam się diabeł wkinie; zachowanie, często związane z odmiennością religijną: Krzycza kieby Żydy w szabas; Kiwa sie jak Żyd nad Talmudem; Brzydzi się jak Żyd stonina; Śmierdzi jak Żyd cebula; Wtóczy się jak Żyd wieczny tułacz; Bać się jak Żyd święconej wody; Czeka jak Żyd na Mesjasza; Obejdzie się żydowskie wesele bez świńskiego mięsa; Żyd czarcie nasienie, dybie na chłopa zniszczenie; Żydzi jak pluskwy: śmierdza jak pluskwy, mnożą sie jak pluskwy i gryza (gryza nas) jak pluskwy; Żyd choć biedny, to nie głupi: przedaj tanio, wszystko kupi; typowe zajęcia i sposoby zarobkowania: Bez jednego Żyda jarmark się obejdzie; Co Żyd to arendarz; Co Żyd to lichwiarz; Gdzie sa Żydki, tam sa dydki; Kiedy bieda, to do Żyda; Kochajmy sie jak bracia, liczmy sie (rachujmy) jak Żydzi; Gdzie sa Żydzi tam człowiek grosza nie widzi; Każdy Żyd swój towar chwali; Gdzie Żyd pisarzem, tam pan gałganiarzem; Gdzie chłop traci, tam się Żyd bogaci. Żydzi oskarżani byli nie tylko o powodowanie różnych nieszczęść, ale i o ogólną nieprzydatność do czegokolwiek: Zaś go Żyd urzekł (upił się); Na żyda tak rachować można jak na zły zegarek; Oj Żydku, Żydku, nie ma z Ciebie żadnego pożytku²5.

${ }^{24}$ Aleksandra Niewiara, analizując wyobrażenia o poszczególnych narodach na podstawie pamiętników, wyróżniła w „wyobrażeniu” Żyda kilka aspektów: fizyczny (inność wyglądu), psychiczny (inteligencja, wykształcenie, dowcip, tchórzostwo, brak patriotyzmu - zdrada polskiej ojczyzny), ekonomiczny (zamożność, uzależnianie od siebie polskiej szlachty), społeczny (określone zajęcia: pisarz, karczmarz, sługa, posłaniec, sprzedawca, lichwiarz, bogaty kupiec, finansista, bankier), religijny (inna wiara), kulturowy (zarost, fryzura, strój). Zob. A. Niewiara, Wyobrażenia o narodach, s. 214-221.

${ }^{25}$ Chociaż chłopi wierzyli również, że Żyd przynosił szczęście, zwłaszcza gdy odwiedził domostwo w Wigilię. Por. teksty opracowane przez B. Maksymiuk, Wszędzie sa ludzie i ludziska. Wspomnienia mieszkańców Krasiczyna i okolic z czasów II wojny światowej, „Etnolingwistyka" 2003, 15, s. 227. 
Negatywny obraz Żyda utrwalony w przysłowiach ukazuje przede wszystkim chłopski punkt widzenia ${ }^{26}$. W publicystyce drugiej połowy XVIII w. stereotyp ten został mocno utrwalony. W Katechizmie o Żydach i neofitach pytanie: "Co to jest Żyd?" znajduje następującą odpowiedź: „Nie stosując tego do wszystkich Żydów, Żyd większą częścią jest to próżniak, matacz, złodziej, szalbierz, wykrętarz i człowiek z przyczyny oddzielnego swej religii fanatyzmu do wspierania sił krajowych niezdatny, a prawie tyle w naszym kraju czyniący pożytku co truteń w ulu między pszczołami"27. Jak stwierdziła Irena Kamińska-Szmaj, stary, negatywny stereotyp Żyda służy w konkretnej sytuacji dziejowej jako narzędzie w walce politycznej, przy czym z obrazu stereotypowego wybierano określone tylko cechy, które były w danym momencie przydatne do celów perswazyjnych. Sytuacja zagrożenia oraz braku poczucia bezpieczeństwa narodowego i społecznego wiązała się zawsze z przywoływaniem i wykorzystywaniem cech stereotypowych.

W latach dwudziestych XX w. stary stereotyp ludowy został swoiście zmodyfikowany: powstał typ Żyda bolszewika-komunisty. Żyd w prasie międzywojennej to przede wszystkim bankier, międzynarodowy finansista, międzynarodowy spiskowiec, komunista, mason, bolszewik, siła rozkładowa, wróg (wewnętrzny, podstępny). Pojawiają się powielane związki frazeologiczne, które „przyjmują postać zbliżoną do gotowych, ustabilizowanych formuł" 28 , jak np. inwazja żydowska czy metody $\dot{z} y d o w-$ skie: „Czytając prasę endecką, można było z mniejszym lub większym prawdopodobieństwem przewidzieć, że obok rzeczowników: rasa, intryga, nienawiść, masoneria, finansjera pojawi się przymiotnik żydowska" ${ }^{29}$. Okres wojny związany jest z wizerunkiem Żyda-ofiary Holokaustu. Po wojnie natomiast Polacy utożsamiali narodowość żydowską z nową, komunistyczną władzą, przyjmowaną wrogo przez większość polskiego społeczeństwa. Stereotyp Żyda-komunisty był znacznie rozpowszechniony (por. hasła w ulotkach antykomunistycznych: „Polacy,

26 Por. też: J. Tazbir, Obraz Żyda w opinii polskiej XVI-XVIII wieku, w: Mity i stereotypy w dziejach Polski, red. J. Tazbir, Warszawa 1991, s. 63-98; A. Cała, op. cit., s. 141-146.

${ }_{27}$ K. Zienkowska, Stereotyp Żyda w publicystyce polskiej w drugiej połowie XVIII w., w: Lud żydowski w narodzie polskim. Materiały sesji naukowej w Warszawie 15-16 wrzesień 1992, red. J. Michalski, Warszawa 1994, s. 87.

${ }_{28}$ I. Kamińska-Szmaj, op. cit., s. 132.

${ }^{29}$ Ibidem. Warto też przypomnieć, że Victor Klemperer uważał, że „antysemityzm jest od początku do końca najskuteczniejszym środkiem propagandowym partii, najskuteczniejszą i najpopularniejszą konkretyzacją doktryny rasistowskiej, bo "Żyda zna każdy»". Żyd w propagandzie hitlerowskiej występował zawsze z epitetami: przebiegły, chytry, oszukańczy, tchórzliwy, platfusowaty, krzywonosy, bojący się wody itd. Por. V. Klemperer, LTI. Notatnik filologa, Warszawa 2014, s. 137, 180-183. 
w ten sposób Niemcy są naszymi wrogami, bolszewicy także, a trzeci wróg to Żydzi. [...] Nie ma miejsca w Polsce dla Niemców, bolszewików, Żydów" 30 .

Gdy obecnie przejrzymy dowolne pisma i portale prawicowe, widzimy, że przywoływanie stereotypu Żyda jest powszechne (zażydzenie Polski, zażydzenie partii). Najczęściej manipuluje się cechami najstarszej warstwy stereotypu: Żyd - pazerny lichwiarz, obcy, niebezpieczny, bogaty, ekspansywny, członek spisku przeciw Polsce (żydowski spisek), wyznawca innej wiary, skrzyżowane z Żydem bolszewikiem-komunistą. Cechy pozytywne stereotypu: pracowitość, przywiązanie do religii i tradycji, inteligencja, umiejętność robienia interesów i organizowania życia rodzinnego są całkowicie pomijane.

W negatywnym stereotypie Żyda rozpowszechnianego przez media prawicowe ujawnia się kilka komponentów: wrogość wobec Polaków, współpraca z Rosją (wcześniej ZSRR, Sowietami, związkiem sowiecko-semickim), manipulacja historią (antypolonizm), wszechpotężny wpływ Żydów na politykę światową (dzięki finansom), bogactwo, sterowanie polską polityką (również za pomocą żydowskich mediów: gazety Szechtera, czyli "Gazety Wyborczej"), nieuczciwość i pazerność, roszczeniowość (która zagraża państwu polskiemu); ekspansywność (zażydzenie Polski). Żyd odpowiada za wszystkie polskie niepowodzenia, co przywołuje starą wizję chłopską i obarczanie Żyda winą za wszelkie nieszczęścia spadające na człowieka.

Pochodzenie żydowskie ciągle jest związane z dyskredytacją ludzi, por. wpis Magdy Ogórek na Twitterze: Panie @MarekBorowski, nawiazujac do wypowiedzi o kręgostupie @Jaroslaw_Gowin-czy oznaka kręgostupa jest zmiana nazwiska z Berman na Borowski?. Co ciekawe, szukanie żydowskich korzeni dotyczy polityków z różnych ugrupowań: T. Mazowieckiego, L. Wałęsy, braci Kaczyńskich, H. Gronkiewicz-Waltz itd. Politycy niezwykle często odwołują się do cech stereotypowych w swoich wpisach internetowych, por.: po wyborach w październiku, będziecie mieli do gadania tyle co żyd w getcie (Zenon Żynda, PiS); Wypoczywam, czytam różne zaległe lektury. I zastanawiam się dlaczego wśród aborterów jest tak dużo Żydów, pomimo holocaustu (Bogdan Rzońca, poseł PiS); Szejnfeld, kaliski żyd ma jakieś kompleksy, Kuczyński Waldemar, rzekomo kaliski żyd, członek PZPR, znawca wszystkiego wie najlepiej; Smolar - etatowy żyd, na UW asystent u Brusa, osławionego siepacza bezpieki; Adam Szejnfeld (prawdopodobnie wyznania mojżeszowego) usituje wmówić nam, katolikom, jak długo mamy upamiętniać

30 B. Szaynok, Polacy i Żydzi. Lipiec 1944 - lipiec 1946, w: Wokót pogromu kieleckiego, red. Ł. Kamiński, J. Żaryn, Kielce 2006, s. 20. 
pamięć naszych bliskich; bezkarność Łzw. żydokomuny, czyli byłych ubeków pochodzenia żydowskiego, których nie można było postawić przed obliczem sprawiedliwości (wpisy Jana Mosińskiego, posła PiS). Piotr Rybak, znany ze spalenia kukły Żyda we Wrocławiu, usiłował przekazać określoną ocenę, stwierdzając, że żona Prezydenta jest Żydówa!!

Niechętny stosunek do Żydów widać zwłaszcza na forach internetowych: Wywalić żydów, wywieźć na Madagaskar tę dzicz; w mediach społecznościowych (opinie osób popularnych w środowiskach nacjonalistycznych), por. wypowiedzi byłego księdza Międlara: Żydzi obsadzaja nawet Stolice Apostolska; Zostałem zatrzymany przez żydowskie służby specjalne!; Żydzi chca nowego mordu (jak na ks. Popiełuszce - przyp. M.M.) na tym katolickim kaptanie; Ciemiężyciele i pasywny żydowski motłoch będzie chciat was rzucić na kolana, przeczołgać, przemielić, przełknać, przetrawić, a na koniec będzie chciał was wypluć, bo jesteście niewygodni (por. także: - Żeby odsunać $\dot{z} y d o s t w o$ od władzy - odpowiedź jednego z uczestników marszu narodowców na pytanie reportera TVP Info o istotę współczesnego patriotyzmu). Z bardzo radykalnych sądów, wyzyskujących negatywne cechy stereotypu Żyda, słynie Stanisław Michalkiewicz, publicysta Radia Maryja, por.: Dla Żydów przewidywana jest rola klasy rządzacej między terenami Rosji a terenami Niemiec; Stary finansowy żydowski grandziarz powierzył [...] dystrybucję swojego jurgieltu na Polskę za pośrednictwem Fundacji Batorego, jak $i \dot{z}$ ydokomuna, będaca w awangardzie komunistycznej rewolucji w Europie Zachodniej, jemu właśnie, to znaczy - Fundacji Batorego powierzyła rozprowadzanie tzw. funduszy norweskich.

W publikacjach radykalnie prawicowych pojawiają się odwołania do chciwości i władzy nad światem (finansowej): PiS wyprzedaje polska ziemię w ręce żydowskie!; Rządza nami żydowscy imperialiści, a przybysze wyrżna nas wszystkich w pień. Unia Europejska widziana jest jako totalitarne państwo rzadzone przez Żydów, tak samo jak USA, Kanada, Australia i inne mniejsze kraje Zachodu; żydowska Bruksela; czopki Sorosa (zwolennicy PO, $\mathrm{UE)}$; żydowski aferzysta (Soros); $\dot{z}$ ydowska propaganda i żydowscy agenci wpływu. Stereotyp chciwego, wykorzystującego innych Żyda przywoływany jest przez polityków, by ożywić niechęć do obcego: - Francuzom zapłacono, Żydom zapłacono, wielu innym narodom zapłacono za straty, które ponieśli w II wojnie światowej, Polakom nie i to przyjmowanie tego faktu jako oczywistego to jest element tej mikromanii narodowej, tego kompleksu, który nam wmawiano (Jarosław Kaczyński).

\section{NIEMIEC - PROTOTYP OBCEGO/WROGA}


Już Jan Stanisław Bystroń zauważył, że Polacy wykazywali skłonność do nazywania Niemcem każdego obcego, por. Francuzi to takie same Niemce, tyle że gorsze $e^{31}$. Zjawisko to można wytłumaczyć kategoryzowaniem Niemca jako prototypowego wroga. Stereotypowi Niemca poświęcił swoją uwagę przede wszystkim Jerzy Bartmiński, ale zajmowały się nim także Krystyna Pisarkowa, Maria Peisert, Aleksandra Niewiara, na materiale pieśni ludowych rekonstruowała go Anna Tyrpa ${ }^{32}$. J. Bartmiński patrzył na stereotyp diachronicznie i wskazał w stereotypie Niemca w Polsce funkcjonowanie kilku profili: najstarszy - Niemiec jako prototyp człowieka obcego, co ma źródła w samej nazwie 'człowiek niemy, niezrozumiały, z którym nie można się porozumieć' (szwargotać, ludowe przysłowia: Gadajże z nim, kiedy on Niemiec; Co Niemiec, to odmieniec). Model ten wsparty przekonaniem o związku Niemca ze złem, diabłem sprawiał, że przypisywano mu cechy demoniczne. Drugi model - Niemiec-pludrak - tworzony z perspektywy szlacheckiej, podkreślający obcość ubioru (pludrak, harcap), kuchni (kartoflarz), religii (heretyk, luter, kalwin), wpisujący się w przysłowie: Póki świat światem, nie będzie nigdy Niemiec Polakowi bratem. Trzeci profil to Niemiec-wróg i reprezentant wysokiej kultury (XIX w.), w stereotypie podkreślane są cechy: bezwzględność, brak zrozumienia i szacunku do innych, brutalność, egoizm, grabieżcość, kult sity, megalomania, okrucieństwo, pogardliwość, przemoc, pycha, siła, niemiecka buta (równocześnie: dyscyplina, ład, umiejętności organizacyjne, pracowitość, pragmatyzm). Czwarty profil - Niemiec-oprawca - jest obrazem budowanym z pozycji ofiary agresji hitlerowskiej: zbrodniarz, okupant, oprawca, hitlerowiec, gestapowiec, SS-man, złoczyńca, sadysta, Szkop, Szwab (pierwotnie neutralny; mieszkaniec Szwabii; por. też oszwabić 'oszukać”), Hitler, Hitlerek. Na ciągle żywe wspomnienia wojny (obraz Niemca-faszysty) w polskiej świadomości zwracała uwagę Krystyna Pisarkowa, analizując wyniki badań podjętych $w$ latach siedemdziesiątych, a potwierdził je $w$ ankietach przeprowadzonych w latach 1990, 1993 i 2000 Jerzy Bartmiński (nacjonalizm, szowinizm, wojna). Ostatni profil wyłoniony przez J. Bartmińskiego to

31 J.S. Bystroń, Megalomania narodowa, Warszawa 1935/1995, s. 72. Por. też: „Trzy narody były znane Wojtkowi: w środku «Polaki», z jednej strony «Moskale», a z drugiej «Niemcy». Ale Niemców były różne gatunki. Chcąc więc być jasnym więcej niż ścisłym, rzekł: - Co to za naród, Francuzy? Jak ci powiedzieć: musi takie Niemcy, tylko jeszcze gorsze... A Bartek na to: - O ścierwa!". H. Sienkiewicz, Bartek zwycięzca, https://wolnelektury.pl/ katalog/lektura/bartek-zwyciezca.html [dostęp: 15 XI 2017].

32 K. Pisarkowa, Konotacja semantyczna nazw narodowości, "Zeszyty Prasoznawcze” 1976, 1, s. 5-26; M. Peisert, Nazwy narodowości i ras we współczesnej polszczyźnie, Język a Kultura, t. 5, red. J. Anusiewicz, F. Nieckula, Wrocław 1992, s. 209-223; A. Niewiara, Wyobrażenia o narodach; A. Tyrpa, Cudzoziemcy i obce kraje w dialektach polskich, Kraków 2011. 
Niemiec-Europejczyk (pracowity, bogaty, kulturalny, gospodarny) ${ }^{33}$.

Stereotyp Niemca wydaje się nadmiernie eksploatowany we współczesnym dyskursie medialnym, zwłaszcza prawicowym. Niemiec to mieszkaniec bogatego kraju, będącego członkiem Unii Europejskiej (UE), ale w mediach polskich funkcjonuje wciąż jako okupant, odwołania do II wojny światowej są powszechne, umiejętnie ożywiane, np. kwestią wojennych reparacji. Można zaobserwować, że ostatnie lata oraz rozwój prasy nurtu prawicowego i narodowego związane są z bardzo charakterystyczną manipulacją cechami stereotypu Niemca, przy czym znika zupełnie przywoływanie cech z profilu najnowszego, ujmującego doświadczenia z lat współistnienia w UE, a wydobywane są wyłącznie cechy Niemca wroga, okupanta, zbrodniarza (por. Każdy pocisk-jeden Niemiec - hasło na marszu narodowców 11 listopada 2017 r.). Nie pojawiają się pozytywne cechy stereotypu Niemca, czyli umiłowanie porządku, dobra organizacja, dokładność. W przestrzeni publicznej sygnalizowane są wyłącznie określenia negatywne: niemieckie pieniądze, niemiecki agent, tragiczna w skutkach polityka Niemiec (o tzw. multikulti), okupacja niemiecka, okupant niemiecki, naziści niemieccy, niemieckie reparacje wojenne, grabież majątku polskiego przez okupanta niemieckiego (w znaczeniu właścicieli sklepów wielkopowierzchniowych lub UE); okupantem nazywa się teraz Brukselę, a więc UE, por.: - Nienawidzę UE, bo jestem Europejczykiem i tak jak dobry Rosjanin nienawidził Zwiazku Sowieckiego, a dobry Niemiec III Rzeszy, tak ja nienawidze UE, nowego okupanta Polski (Janusz Korwin-Mikke); z formalnego punktu widzenia Polska jest pod okupacją Unii Europejskiej (poseł Kukiz'15 Jacek Wilk); - Hitler nie miał Boga w sercu. To tak jak Unia Europejska teraz (Tadeusz Rydzyk), por.: fora internetowe: UNIA EUROPEJSKA TO JEDEN WIELKI OKUPANT!; Unia - okupant, nastepca Hitlera; - Unia Europejska jest jak Hitler!; Nowe przelewy z Niemiec na walkę z PiS. Ogromne środki na Aktion Demokratie ${ }^{34}$; $K O D^{35}$ w objęciach niemieckiego rzadu; "Czyim kandydatem jest Donald Tusk?" pytaja dziennikarze. "Angeli Merkel, jest kandydatem niemieckim” (Jarosław Kaczyński). W ostatnich miesiącach karierę robią reparacje wojenne od Niemiec, co na pewno jest związane z ożywianiem wspomnień wojennych, por.: $W$ sprawie reparacji my będziemy chcieli dą̇yć do tego, aby zadośćuczynić Polsce, Polakom, ofiarom Niemiec hitlerowskich i niemieckich obozów śmierci, żeby strona niemiecka takowe odszkodowania wypłaciła (Jan Mosiński); Okupant najpierw niemiecki,

33 J. Bartmiński, Zmiany stereotypu, s. 225-237.

34 Chodzi o Akcję Demokrację, która organizuje różne akcje obywatelskie. Przez skrajną prawicę organizacja ta jest posądzana o przyjmowanie finansowania płynącego z Niemiec.

35 KOD (Komitet Obrony Demokracji) - ruch społeczny przekształcony w stowarzyszenie założone z inicjatywy Mateusza Kijowskiego w grudniu 2015 r. KOD przeciwstawia się nadużyciom rządów „dobrej zmiany” i łamaniu zasad praworządności. 
potem sowiecki nie musiał się liczyć z polskim wyznaniem, tradycja czy obyczajem (Józefina Hrynkiewicz). Przypisywanie cechy niemieckości jest sposobem dyskredytowania poszczególnych osób publicznych, por. np.: Donald Tusk, który w mojej opinii, w mojej ocenie, a szczególnie po tych słowach w odniesieniu do premier polskiego rzadu, jest takim niemieckim popychlem, zareagowat tak nerwowo $i$ alergicznie na te słowa być może dlatego, że pani premier w swoim wystapieniu odwołała sie do tego, kto to piekło na ziemi zgotowat. Nazywajac zbrodniarzy wprost - niemieckimi nazistami, nie jakimś ponadnarodowym towarzystwem. Tylko mówiąc wprost, że to Niemcy (Joachim Brudziński); Pani się nie czuje w tej chwili Polka, pani się czuje reprezentantka Niemiec i to pani nam dzisiaj robi (Tomasz Sakiewicz do Róży Thun ${ }^{36}$ ).

Posłanka PiS Krystyna Pawłowicz zamieściła na Facebooku wpis, w którym sugerowała, że ukonstytuowała się opozycyjna do polskich władz centralnych niemiecka republika gdańska wraz z delegatami obecnej opozycji. Zadała też pytanie, dlaczego Polacy mieszkajacy w polskim Gdańsku godza się na to antypolskie, nielojalne wobec swej Ojczyzny demonstracyjne przedstawienie. Przywołując konotacje przymiotnika niemiecki, w pośredni sposób oceniła postępowanie prezydenta Gdańska, organizującego święto Trybunału Konstytucyjnego.

Przytoczony materiał językowy wskazuje, że polska prawica z upodobaniem manipuluje cechami stereotypu Niemca, wyzyskując zwłaszcza te cechy, które kojarzą się z okresem okupacji i zbrodniami wojennymi. Trzeba też zauważyć, że właśnie na tej bazie (skojarzenie z hitleryzmem) budowany jest obraz całej Unii Europejskiej.

\section{ROSJANIN - NASZ BRAT I SZPIEG}

Stereotypem Rosjanina zajmowali się lubelscy etnolingwiści: Jerzy Bartmiński, Irina Lappo, Urszula Majer-Baranowska (w dalszej części artykułu przytaczam ich wnioski), a także Aleksandra Niewiara ${ }^{37}$. Nazwy używane w stosunku do Rosjan są zwykle nacechowane emocjonalnie:

36 Profil Róży Thun na Wikipedii był wielokrotnie zmieniany przez anonimowych internautów: fragment „polska działaczka organizacji pozarządowych, publicystka” został przemianowany na "niemiecka działaczka organizacji pozarządowych, reprezentująca niemieckie interesy narodowe w Polsce publicystka, posługująca się Polskim językiem". W komentarzach na forum posłankę nazywano Róża Thun von hande hoch, Róża Thun von Ribentrop, Róża von Panzerfaust. Por. http://www.rp.pl/Platforma-Obywatelska/170819290Biografia-Rozy-Thun-na-Wikipedii-zablokowana-Chcieli-zrobic-z-niej-Niemke.html [dostęp: 15 X 2017].

37 J. Bartmiński, I. Lappo, U. Majer-Baranowski, op. cit., s. 105-151; I. Lappo, Profilowanie stereotypu, s. 153-174; A. Niewiara, Wyobrażenia o narodach; eadem, Moskwicin Moskal - Rosjanin w dokumentach prywatnych. Portret, Łódź 2006. 
Ruscy, Ruskie, Sowieci; bolszewicy, Rusole, Ruchole, Ruchol, Ruchale; Kacapy, Kałmuki, Wielki Brat Swołocz/Ruska swołocz; przyjaciele ze Wschodu, Wanie, Iwany, por. pochodne od nich czasowniki: podiwanić 'ukraść', przyiwanić, doiwanić 'uderzyć się lub kogoś', Sasze, Tamary i Wowy ${ }^{38}$. Czasowniki rusyfikować, ruszczyć oraz rzeczownik rusyfikacja mają negatywne konotacje, wiążą się z zaborami i narzucaniem Polakom kultury i języka rosyjskiego. Ma to związek również z łączliwością wyrazową typu: zabór rosyjski, imperium rosyjskie. II wojna światowa odzwierciedlona jest w połączeniach: czołg rosyjski, armia rosyjska, żołnierz rosyjski.

J. Bartmiński, I. Lappo i U. Majer-Baranowska (a dokładniej czyni to I. Lappo) wyróżniają w opisie Rosjanina kilka utrwalonych punktów widzenia, a więc profili stereotypu: 1) punkt widzenia prostego człowieka: ludowy profil brata-wroga, na który składają się syndromy słowiańskiej swojskości, rosyjskiej duszy, Azjaty, agresora i jednocześnie niewolnika. Cechy charakterystyczne dla tego profilu to: fizyczna krzepa, agresywność i duchowa więź z Polakiem (Słowianie, pijaństwo); 2) punkt widzenia polskiego patrioty - profil Rosjanina-zaborcy: na obraz ten składają się: syndrom władcy-niewolnika oraz tzw. człowieka radzieckiego, wyznawcy zbrodniczej ideologii, dążącego do dominacji nad innymi; 3) punkt widzenia inteligenta - profil przyjaciela Moskala - człowieka kulturalnego, wrażliwego i myślącego; profil ten jest związany $\mathrm{z}$ aktywizacją syndromu Rosjanina jako nosiciela bogatej kultury narodowej (więź z tradycją i kulturą narodową muzykalność, zamiłowanie do tańca, zabawy, współtwórca światowej kultury; 4) punkt widzenia wykształconego, proeuropejskiego pragmatyka - Rosjanin jako partner, Europejczyk o podobnych aspiracjach życiowych i zbliżonym systemie wartości ${ }^{39}$.

W prawicowej prasie wykorzystywanie stereotypu Rosjanina jest nieco skromniejsze niż pozostałych dwóch. W ubiegłych latach (przed 2010 r.) sygnalizowany był głównie lekceważący stosunek Rosjan do Polaków i chęć zdominowania państwa polskiego. Po wypadku smoleńskim Rosjanie zaczęli być oskarżani o zamach (rosyjski zamach) i zaczęły być aktywizowane negatywne cechy stereotypu. Przypominana jest też polska historia i wrogie działania sąsiadów Polski: Podczas II wojny światowej znowu Niemcy i Rosjanie mordowali z premedytacja polska inteligencję. W PRL-u na jej miejsce wprowadzano "inteligencje pracujaca" $z$ "awansu społecznego", albo wprost importowana ze Zwiazku Sowieckiego. To była jakość!

38 Por. też M. Peisert, op. cit., s. 215.

39 J. Bartmiński, I. Lappo, U. Majer-Baranowska, op. cit., s. 105-151; I. Lappo, op. cit., s. $153-174$. 
W ubieganiu sie na studia dodatkowe punkty za pochodzenie miaty za zadanie wykluczyć dzieci "czarnej reakcji”. Tak powstała polskojęzyczna wspólnota rozbójnicza pasożytująca na Polakach (Maria Zuba); Rosja i Niemcy pociagaja za sznurki (Jerzy Targalski).

$\mathrm{W}$ dyskursie publicznym sygnalizuje się przede wszystkim elementy związane z rosyjska propaganda, analizuje się rosyjskie powiazania polskich polityków, czyli szuka się rosyjskich łączników lub rosyjskich agentów (rosyjski wywiad, rosyjska agentura, rosyjski szpieg, szpieg Kremla, agent Kremla, agent Putina, agentura Putina). Kontakty z Rosjanami często nazywane są niejasnymi, obserwowane są rosyjskie wpływy w Polsce lub na świecie (polityków zależnych od Rosji nazywa się rosyjskimi marionetkami). Wpływy rosyjskie są możliwe dzięki rosyjskiemu kapitałowi, a potęga państwa budowana jest na surowcach, np. rosyjskim gazie, na odpowiednim przygotowaniu bojowym: rosyjska rakieta, rosyjski bombowiec, rosyjskie sity zbrojne, rosyjski wywiad wojskowy, rosyjski bezzałogowy samolot szpiegowski. O sposobach działania Rosjan świadczą połączenia wyrazowe: rosyjska mafia, rosyjska $V$ kolumna w Polsce, trolle ruskie, trolle rosyjskie, trolle Putina, rosyjska swołocz lub wypowiedzi typu: PIS jest cicho, a Rosjanie nas szpieguja.

Podobnie jak w przypadku pozostałych stereotypów, skojarzenie z Rosją jest sposobem na dyskredy towanie przeciwnika politycznego lub instytucji europejskich: PetRU; Kumple Macierewicza: agent, lobbysta i fan Putina; Tusk i fundacja wnuka Mołotowa: Jak wystannicy Kremla harcowali w Polsce; - Nienawidze tego ścierwa sowieckiego, którym jest Unia Europejska (Wojciech Cejrowski); Macierewicz działa jak rosyjski agent (Kazimierz Marcinkiewicz); Nie tylko Niemcy, ale też Rosja musi nam zapłacić odszkodowania wojenne za II wojnę światową! (Stanisław Pięta, Małgorzata Gosiewska); A lista krzywd jest przecież niewyobrażalna. Wystarczy wymienić choćby zbrodnię katyńska, masowe wywózki w głąb ZSRR czy obławe augustowska. - Odszkodowania od Rosji winny sięgać bilionów złotych! (Stanisław Pięta); Rosjanie graja śledztwem smoleńskim (Witold Waszczykowski); Mam niemal pewność, że Rosjanie matacza. Jeśli się złoży w całość informacje, które naptywaja, nawet jeśli odnosza się do różnych scenariuszy, a także weźmie się pod uwage ewentualne intencje Rosjan, to można powiedzieć, choć bez stuprocentowej pewności, że Rosja jest w jakimś sensie odpowiedzialna za ten nowy Katyń (Artur Górski).

Wydaje się, że w świadomości Polaków Rosjanie ciągle są mniej obcy niż Niemcy i Żydzi. Coraz częściej w opiniach zamieszczanych na forach internetowych pojawia się także idea wspólnej Słowiańszczyzny (i wyraźne przeciwstawianie się Niemcom): Zaczęło się wyzwalanie. Dziś Ukraina, jutro Polska będzie wyzwolona. A te co tu pisza na nas Stowian wiedza i trzęsa krótkimi portkami bo sprawiedliwość nadchoddzi. Narodowcy kibice 
i ludzie Lepera się odrodza i wyzwola naród od niemca. Wielka Rosja i wielka Polska się odrodzą $q^{40}$.

Jak widzimy, stereotypy służą członkom społeczności jako wspólne dla wszystkich schematy myślenia, gotowe elementy, z których można budować określony obraz świata. Niewątpliwie siłą (i słabością) stereotypów narodowych jest ich odporność na zmiany: mimo przeobrażeń kulturowych, historycznych, gospodarczych i mentalnych cechy stereotypowe charakteryzują się wysoką trwałością. W sytuacji, kiedy naród nie odczuwa zagrożenia ze strony INNEGO/OBCEGO, zazwyczaj nie ma potrzeby manipulowania treściami stereotypowymi. Wystarczy jednak poczucie zagrożenia, by OBCY stał się groźny. Stereotypy etniczne nie są poważnym źródłem informacji o innych nacjach, ale z pewnością stanowią niezwykle wiarygodną bazę wiedzy o nas samych, o naszych społecznych lękach, które są wyzyskiwane niezwykle skutecznie w propagandzie, działającej nie tylko za pomocą słów, ale także obrazów (por. okładki wybranych czasopism, np. „Gazety Polskiej”, ,wSieci”).

\section{BIBLIOGRAFIA (REFERENCES)}

\section{Opracowania}

Bartmiński J., Lappo I., Majer-Baranowska U., Stereotyp Rosjanina i jego profilowanie we współczesnej polszczyźnie, „Etnolingwistyka” 2002, 14.

Bartmiński J., Nasi sasiedzi w oczach studentów, w: Narody i stereotypy, red. T. Walas, Kraków 1995.

Bartmiński J., Panasiuk J., Stereotypy językowe, w: Encyklopedia kultury polskiej XX wieku, t. 2: Wspótczesny język polski, red. J. Bartmiński, Wrocław 1993.

Bartmiński J., Pojęcie językowego obrazu świata i sposoby jego operacjonalizacji, w: Jaka antropologia literatury jest dzisiaj możliwa?, red. P. Czapliński, A. Legeżyńska, M. Telicki, Poznań 2010.

Bartmiński J., Zmiany stereotypu Niemca w Polsce. Profile i ich historyczno-kulturowe uwarunkowania, w: Profilowanie w jezyku i tekście, red. J. Bartmiński, R. Tokarski, Lublin 1998.

Brzezina M., Polszczyzna Żydów, Warszawa-Kraków 1986.

Bystroń J.S., Megalomania narodowa, Warszawa 1935/1995.

Cała A., Wizerunek Żyda w polskiej kulturze ludowej, Warszawa 1992.

Chlebda W., O źródłach, celach i drogach postępowania etnolingwistycznego w badaniach porównawczych, „Studia Slavica. Slovanské Studie” 2010, 14.

Delumeau J., Strach w kulturze Zachodu XIV-XVIII w., Warszawa 1986.

Girard R., Kozioł ofiarny, Łódź 1987.

Głowiński M., Nowomowa i ciagi dalsze. Szkice dawne i nowe, Kraków 2009.

Kamińska-Szmaj I., Judzi, zohydza, ze czci odziera. Język propagandy politycznej w prasie 19191923, Wrocław 1994.

Język w IV Rzeczypospolitej, red. M. Czerwiński, P. Nowak, R. Przybylska, Lublin 2010.

Karłowicz J., Kryński A., Niedźwiedzki W., Słownik języka polskiego, t. 8, Warszawa 1927.

40 Por. http://forum.pomorska.pl/modle-sie-za-rosyjskich-braci-i-wladimira-putinat193810/page-11 [dostęp: 15 X 2017]. 
Klemperer V., LTI. Notatnik filologa, Warszawa 2014.

Lappo I., Profilowanie stereotypu Rosjanina w polskim kręgu językowo-kulturowym, „Etnolingwistyka" 2002, 14.

Maksymiuk B., Wszędzie sa ludzie i ludziska. Wspomnienia mieszkańców Krasiczyna i okolic z czasów II wojny światowej, „Etnolingwistyka” 2003, 15.

Marczewska M., Żyd - obraz utrwalony w języku, w: Z przeszłości Żydów polskich od XVI do końca XX wieku. Polityka-Gospodarka - Kultura - Społeczeństwo, red. R. Renz, J. Wijaczka, Kraków 2005.

Marczewska M., Swój i obcy w mieście - kilka uwag o stereotypie kielczanina (rzecz o stosunkach polsko-żydowskich), „Etnolingwistyka” 2007, 19.

Niebrzegowska-Bartmińska S., Aksjologiczne tło demonizacji przeciwnika w kampanii wyborczej 2007 roku, w: Język IV Rzeczypospolitej, red. M.. Czerwiński, P. Nowak, R. Przybylska, Lublin 2010.

Niewiara A., Moskwicin - Moskal - Rosjanin w dokumentach prywatnych. Portret, Łódź 2006.

Niewiara A., Polskie stereotypy narodowe w świetle badań diachronicznych, „LingVaria” 2010, 2 (10).

Niewiara A., Wyobrażenia o narodach w pamiętnikach i dziennikach z XVI-XIX wieku, Katowice 2000.

Pajdzińska A., My, to znaczy... (z badań językowego obrazu świata), „Teksty Drugie: teoria literatury, krytyka, interpretacja" 2001, 66, 1.

Peisert M., Nazwy narodowości i ras we współczesnej polszczyźnie, w: Język a Kultura, t. 5, red. J. Anusiewicz, F. Nieckula, Wrocław 1992.

Pisarkowa K., Konotacja semantyczna nazw narodowości, „Zeszyty Prasoznawcze” 1976, 1.

Robins R.S., Post J.M., Paranoja polityczna: psychopatologia nienawiści, Warszawa 1999.

Stownik języka polskiego, red. W. Doroszewski, wersja internetowa: http://www.sjpd.pwn. pl/ [dostęp: 26 I 2019].

Szaynok B., Polacy i Żydzi. Lipiec 1944 - lipiec 1946, w: Wokót pogromu kieleckiego, red. Ł. Kamiński, J. Żaryn, Kielce 2006.

Śpiewak P., Pięć lat po czwartej. Dlaczego wymyśliłem IV RP, „Polityka” 22/2010 (29 V 2010), wersja cyfrowa: https://www.polityka.pl/tygodnikpolityka/kraj/1506800,1,dlaczegowymyslilem-iv-rp.read [dostęp: 9 VI 2018].

Tazbir J., Obraz Żyda w opinii polskiej XVI-XVIII wieku, w: Mity i stereotypy w dziejach Polski, red. J. Tazbir, Warszawa 1991.

Tyrpa A., Cudzoziemcy i obce kraje w dialektach polskich, Kraków 2011.

Zienkowska K., Stereotyp Żyda w publicystyce polskiej w drugiej połowie XVIII w., w: Lud żydowski w narodzie polskim. Materiaty sesji naukowej w Warszawie 15-16 wrzesień 1992, red. J. Michalski, Warszawa 1994.

\section{Strony internetowe}

http://forum.pomorska.pl/modle-sie-za-rosyjskich-braci-i-wladimira-putina-t193810/ page-11 [dostęp: 15 X 2017].

http://interwencjaprawna.pl/docs/ARE-116-uprzedzenia-mlodych-polakow.pdf [dostęp: 15 XII 2017].

https://wolnelektury.pl/katalog/lektura/bartek-zwyciezca.html [dostęp: 15 XI 2017].

https://www.polityka.pl/tygodnikpolityka/kraj/1506800,1,dlaczego-wymyslilem-iv-rp. read [dostęp: 9 VI 2018].

http://www.rp.pl/Platforma-Obywatelska/170819290-Biografia-Rozy-Thun-na-Wikipediizablokowana-Chcieli-zrobic-z-niej-Niemke.html [dostęp: 15 X 2017].

http://wyborcza.pl/duzyformat/1,127290,18447691,dlaczego-5-tys-polakow-polubilomem-z-muzulmanami-i-torami.html [dostęp: 20 X 2017].

Okładki tygodnika „wSieci” („wSieci Prawdy”): nr 41 (45)/2013 [Prawie jak Goebbels]; nr 43 
(47)/2013 [Nieznane zdjęcie - Smoleńsk 10.04.2010]; nr 40 (96)/2014 [Polska ma prawo żadać od Niemców $845 \mathrm{ml}$ dol. Sensacyjne wyniki naszego śledztwa: Nigdy nie zrzekliśmy się odszkodowań za II wojne światowa]; nr 17 (126)/2015 [Lichwa platformersko-kremlowska. Powiazany $z$ Moskwa gigant finansowy przejmuje rynek lichwiarskich pożyczek $w$ Polsce. Przy wsparciu władzy]; nr 38 (147)/2015 [Ewa Kopacz urzadzi nam piekło na rozkaz Berlina]; nr 2 (163)/2016 [Od Targowicy do KOD. Od carycy Katarzyny do Merkel. Spisek przeciw Polsce]; nr 44 (205)/2016 [Na smyczy Putina]; nr 12 (225)/2017 [Instrukcje do ataku na polski rzad przychodza z zagranicy]; nr 13 (226)/2017 [Nadzorca z Niemiec redagowat polskie gazety]; nr 30 (243)/2017 [Pięścią i zagranica chca zablokować naprawę Polski]; nr 32 (245)/2017 [6 bilionów dolarów sa nam winni Niemcy za horror wojny]; https://www.wsieciprawdy.pl/archiwum.html [dostęp: 16 VII 2018].

\section{ABSTRACT}

I regard a stereotype as a kind of colloquial conceptualization of reality, a component of the linguistic image of the world and the linguistic-cultural code. The paper focuses on the manipulation of several ethnic stereotypes (German, Russian, Jew) in contemporary Polish public discourse. The analysis is based on a variety of linguistic data: the so-called system data and texts (press materials: newspaper and magazine articles, Internet posts, statements of politicians and Internet users in social media, semiotically complex texts: graphic and verbal-graphic expressions) to show how negative elements of stereotypes are used in the political combat in the media.

Key words: stereotypes, linguistic image of the world, manipulation, politics

\section{NOTA O AUTORZE}

Marzena Marczewska - doktor habilitowany, pracownik Instytutu Filologii Polskiej Uniwersytetu Jana Kochanowskiego w Kielcach, specjalizuje się w etnolingwistyce i komunikacji językowej. Autorka książek: Drzewa w języku i w kulturze (Kielce 2002) oraz Ja cię zamawiam, ja cie wypędzam. Choroba. Studium językowo-kulturowe (Kielce 2012). E-mail: marzenamar@onet.pl 